Article

\title{
New Diterpenoids from Soft Coral Sarcophyton ehrenbergi
}

\section{Shang-Kwei Wang ${ }^{1,2}$, Mu-Keng Hsieh ${ }^{3}$ and Chang-Yih Duh ${ }^{1,3, *}$}

1 Asia-Pacific Ocean Research Center, National Sun Yat-sen University, Kaohsiung 804, Taiwan;

\author{
E-Mail: skwang@cc.kmu.edu.tw
}

2 Department of Microbiology, Kaohsiung Medical University, Kaohsiung 807, Taiwan

3 Department of Marine Biotechnology and Resources, National Sun Yat-sen University, Kaohsiung 804, Taiwan

* Author to whom correspondence should be addressed; E-Mail: yihduh@mail.nsysu.edu.tw; Tel.: +886-7-525-2000 (ext. 5036); Fax: +886-7-525-5020.

Received: 23 September 2013; in revised form: 18 October 2013 / Accepted: 22 October 2013 / Published: 30 October 2013

\begin{abstract}
Continuing chemical investigation on the acetone extracts of the soft coral Sarcophyton ehrenbergi collected off the coast of San-hsian-tai, Taitong County, Taiwan led to the isolation of two new diterpenoids, ehrenbergol $\mathrm{C}$ and acetyl ehrenberoxide B (1 and 2). The structures of these isolated metabolites were elucidated through extensive spectroscopic analyses. Moreover, in vitro tests show that compounds 1 and 2 displayed antiviral activity towards human cytomegalovirus, with $\mathrm{EC}_{50}$ of 20 and $8.0 \mu \mathrm{g} / \mathrm{mL}$, respectively.
\end{abstract}

Keywords: Sarcophyton ehrenbergi; diterpenoids; cytotoxicity; anti-HCMV

\section{Introduction}

Marine organisms, which have developed unique metabolic and physiological capabilities to ensure survival in extreme marine habitats, offer the potential to produce novel bioactive secondary metabolites that would not be produced by terrestrial organisms [1]. Soft corals of the genus Sarcophyton have been reported as a rich source of diterpenoids [1]. These constituents, mainly macrocyclic cembranes and their derivatives, represent important chemical defense substances for the animals against their natural predators [2]. Cembranoids have been previously reported to exhibit a range of biological activities including antitumor [3-9], ichthyotoxic [10], anti-inflammatory [11], 
neuroprotective [12], antibacterial [13], antiangiogenic [14], antimetastatic [14], anti-osteoporotic [15], cytotoxic [16-18] and antiviral properties [19,20].

Fifteen cembranoids were previously reported from the Taiwanese soft coral Sarcophyton ehrenbergi [19-21]. Continuing chemical investigation of the soft coral S. ehrenbergi (Figure 1) collected at San-Hsian-Tai (Taitong County, Taiwan) resulted in the isolation of two new diterpenoids, designated as ehrenbergol $\mathrm{C}$ and acetyl ehrenberoxide B (1 and 2) (Figure 2). Herein, we describe the purification, structure elucidation, cytotoxicity and antiviral evaluation of these metabolites.

Figure 1. Soft coral Sarcophyton ehrenbergi.

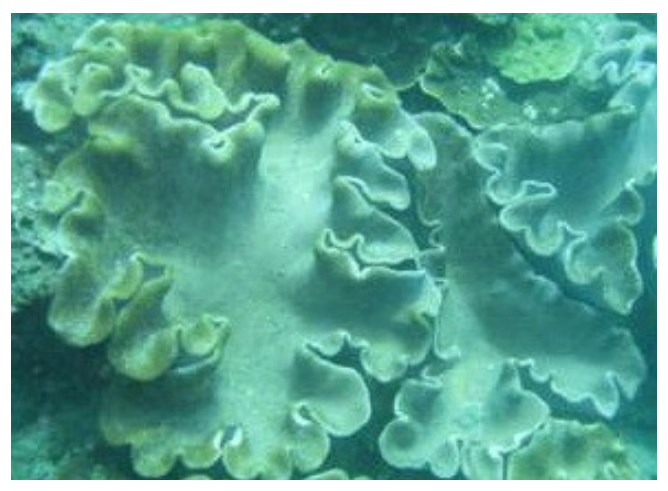

Figure 2. Structures of compounds 1 and 2.

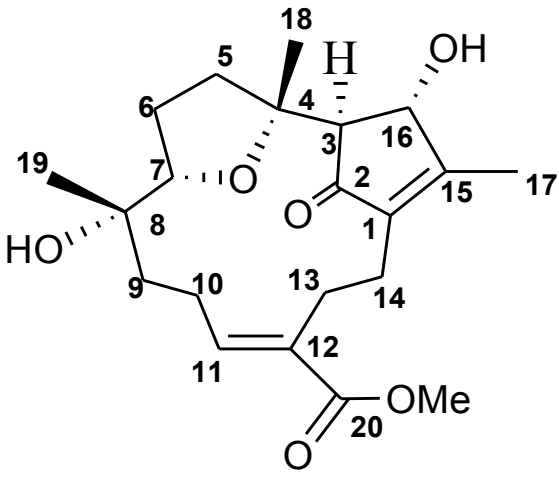

1

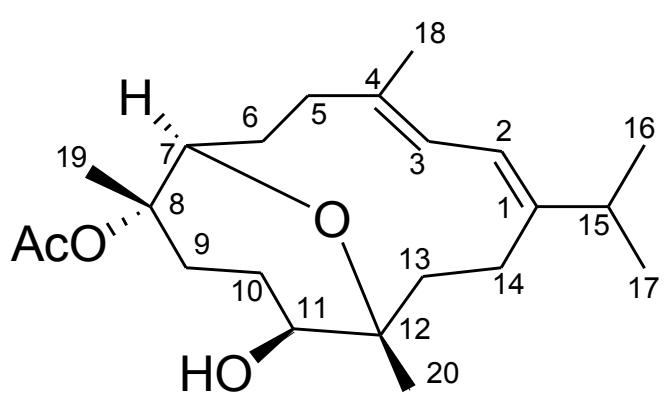

2

\section{Results and Discussion}

Compound 1 was isolated as a colorless oil, $[\alpha]^{25}+95.0\left(c 0.2, \mathrm{CHCl}_{3}\right)$. The IR spectrum of 1 exhibited absorptions due to hydroxyl $\left(3444 \mathrm{~cm}^{-1}\right)$ and conjugated enone $\left(1696 \mathrm{~cm}^{-1}\right)$ functionalities. The presence of the conjugated enone was also confirmed by the UV spectrum $\left[\lambda_{\max }(\log \varepsilon) 223 \mathrm{~nm}\right.$ (3.42)]. HRESIMS exhibited a pseudo molecular ion peak at $m / z 401.1939[\mathrm{M}+\mathrm{Na}]^{+}$, consistent with the molecular formula of $\mathrm{C}_{21} \mathrm{H}_{30} \mathrm{O}_{6}$.

The structure of 1 was solved by a combination of 1D and 2D NMR methods. The resonances at $\delta_{\mathrm{C}} 205.9(\mathrm{qC}), 141.4(\mathrm{qC})$, and $168.9(\mathrm{qC})$, in the ${ }^{13} \mathrm{C}$ NMR and DEPT spectra suggested the presence of a tetrasubstituted conjugated enone (Table 1). Furthermore, the presence of four oxygenated carbons was inferred from the carbon signals at $\delta_{\mathrm{C}} 73.9(\mathrm{qC}), 83.2(\mathrm{qC}), 85.6(\mathrm{CH})$, and $75.4(\mathrm{CH})$. NMR spectroscopic data $\left[\delta_{\mathrm{H}} 6.76(1 \mathrm{H}, \mathrm{t}, J=7.2 \mathrm{~Hz})\right.$ and $3.75(3 \mathrm{H}, \mathrm{s}) ; \delta_{\mathrm{C}} 168.2(\mathrm{C}, \mathrm{C}-20), 130.7(\mathrm{C}, \mathrm{C}-12)$, 
$144.7(\mathrm{CH}, \mathrm{C}-11)$, and $\left.51.6\left(\mathrm{CH}_{3}, \mathrm{COOMe}\right)\right]$ revealed the presence of an $\alpha, \beta$-unsaturated methyl ester functionality. Six methylene groups were deduced from six triplet signals at $\delta_{\mathrm{C}} 36.6,34.3,28.5,24.3$, 23.8, and 21.8, a methine signal at $\delta_{\mathrm{C}} 60.8$, and, finally, three methyl signals at $\delta_{\mathrm{C}} 13.4,28.4$, and 24.2.

Table 1. NMR data for compound 1.

\begin{tabular}{|c|c|c|c|c|c|}
\hline Position & $\delta_{\mathrm{H}}^{\mathrm{a}}(J$ in $\mathrm{Hz})$ & $\delta_{\mathrm{C}}^{\mathrm{b}}$, type & HMBC & COSY & NOESY \\
\hline 1 & & 141.4, qC & & & \\
\hline 2 & & 205.9, qC & & & \\
\hline 3 & $2.13, \mathrm{~d}(2.0)$ & $60.8, \mathrm{CH}$ & $2,4,16$ & 16,18 & $5 a$ \\
\hline 4 & & $83.2, \mathrm{qC}$ & & & \\
\hline $5 a$ & 3.11, ddd $(12.0,8.8,3.2)$ & $34.3, \mathrm{CH}_{2}$ & & $6 b, 18$ & 3 \\
\hline $5 b$ & $1.67 \mathrm{~m}$ & \multirow{3}{*}{$28.5, \mathrm{CH}_{2}$} & 6 & & 18 \\
\hline $6 a$ & $1.56, \mathrm{~m}$ & & & 7 & \\
\hline $6 b$ & $1.84, \mathrm{~m}$ & & 7 & $5 a, 7$ & 7 \\
\hline 7 & $3.82, \mathrm{dd}(10.4,6.0)$ & $85.6, \mathrm{CH}$ & 8,9 & $6 a, 6 b$ & $6 b, 19$ \\
\hline 8 & & 73.9, qC & & & \\
\hline $9 \mathrm{a}$ & $1.59, \mathrm{~m}$ & \multirow{3}{*}{$36.6, \mathrm{CH}_{2}$} & $8,10,11$ & & \\
\hline $9 b$ & $1.45, \mathrm{~m}$ & & $8,10,11$ & 10 & \\
\hline $10 \mathrm{a}$ & $1.98, \mathrm{~m}$ & & & $9 b, 11$ & $13 b$ \\
\hline $10 \mathrm{~b}$ & $1.99, \mathrm{~m}$ & $23.8, \mathrm{CH}_{2}$ & 9,12 & $9 b, 11$ & 11,19 \\
\hline 11 & $6.76, \mathrm{t}(7.2)$ & $144.7, \mathrm{CH}$ & $9,10,20$ & 10 & $10 \mathrm{~b}$ \\
\hline 12 & & $130.7, \mathrm{qC}$ & & & \\
\hline $13 \mathrm{a}$ & $2.46, \mathrm{~m}$ & $24.3, \mathrm{CH}_{2}$ & $11,12,14,20$ & 14 & \\
\hline $13 b$ & $2.63, \mathrm{~m}$ & & $1,11,12,14,20$ & 14 & $14 \mathrm{a}$ \\
\hline $14 \mathrm{a}$ & $2.46, \mathrm{~m}$ & $21.8, \mathrm{CH}_{2}$ & $1,2,13,15$ & 13 & $13 b$ \\
\hline $14 \mathrm{~b}$ & $2.47, \mathrm{~m}$ & & & 13 & 17 \\
\hline 15 & & $168.9, \mathrm{qC}$ & & & \\
\hline 16 & $4.92, \mathrm{~d}(6.0)$ & $75.4, \mathrm{CH}$ & $1,4,15$ & 3,17 & 17,18 \\
\hline 17 & $1.94, \mathrm{~s}$ & $13.4, \mathrm{CH}_{3}$ & $1,15,16$ & 16 & $14 b, 16$ \\
\hline 18 & $1.42, \mathrm{~s}$ & $28.4, \mathrm{CH}_{3}$ & $3,4,5$ & $5 a$ & $7,5 b, 16$ \\
\hline 19 & $1.09, \mathrm{~s}$ & $24.2, \mathrm{CH}_{3}$ & $7,8,9$ & & $6 a, 7,10 b$ \\
\hline 20 & & $168.2, \mathrm{qC}$ & & & \\
\hline $\mathrm{OMe}$ & $3.75, \mathrm{~s}$ & $51.6, \mathrm{CH}_{3}$ & 20 & & \\
\hline
\end{tabular}

${ }^{\mathrm{a}}$ Spectra were measured in $\mathrm{CDCl}_{3}(400 \mathrm{MHz}){ }^{\mathrm{b}}$ Spectra were measured in $\mathrm{CDCl}_{3}(100 \mathrm{MHz})$.

The combined use of ${ }^{1} \mathrm{H}-{ }^{1} \mathrm{H}$ COSY and HMQC on $\mathbf{1}$ allowed us to distinguish four spin systems (Figure 3a-d). A HMBC experiment was used to assemble the skeletal fragments through quaternary carbons and heteroatoms. Thus, these substructures were connected through HMBC correlations between the protons $\mathrm{H}_{2}-14\left(\delta_{\mathrm{H}} 2.46\right)$ and the carbons $\mathrm{C}-1\left(\delta_{\mathrm{C}} 141.4\right), \mathrm{C}-2\left(\delta_{\mathrm{C}} 205.9\right), \mathrm{C}-15\left(\delta_{\mathrm{C}} 168.9\right)$, and $\mathrm{C}-12\left(\delta_{\mathrm{C}} 130.7\right)$, between the methine proton $\mathrm{H}-3\left(\delta_{\mathrm{H}} 2.13\right)$ and carbon $\mathrm{C}-2$, between the methyl protons Me-19 and the carbon C-7, C-8 and C-9, between the methyl protons Me-18 $\left(\delta_{\mathrm{H}} 1.42\right)$ and carbons C-3 $\left(\delta_{\mathrm{C}} 60.8\right), \mathrm{C}-4\left(\delta_{\mathrm{C}} 83.2\right)$, and C-5 ( $\left.\delta_{\mathrm{C}} 34.3\right)$, and between $\mathrm{H}_{2}-13 / \mathrm{H}-11 / \mathrm{OMe}-20$ and the carbon $\mathrm{C}-20$. These relationships are represented in Figure 3.

All these data allowed us to identify compound $\mathbf{1}$ having the same planar framework as lobocrasol isolated from soft coral Lobophytum crassum [22]. With the gross structure of $\mathbf{1}$ in hand, the relative 
stereochemistry of compound 1 was deduced from NOESY correlations and Chem3D Ultra 9.0 (Figure 4). The $Z$ geometry of the $\Delta^{11}$ double bond was established by the NOESY correlation observed between $\mathrm{H}-11$ and $\mathrm{H}-10 \mathrm{~b}$ and between H-10a and H-13b. NOESY correlations between $\mathrm{H}-7 / \mathrm{H}_{3}-19, \mathrm{H}-7 / \mathrm{H}_{3}-18$, and $\mathrm{H}_{3}-18 / \mathrm{H}-3$ indicated that these protons are on the same face of the ring system, thereby establishing the relative configuration of $\mathbf{1}$. The relative stereochemistry of $\mathrm{C}-7$ and C-8 were different from lobocrasol; however, the absolute structure was not determined due to the limited amount of the sample.

Figure 3. COSY and HMBC correlations of compounds $\mathbf{1}$ and 2.

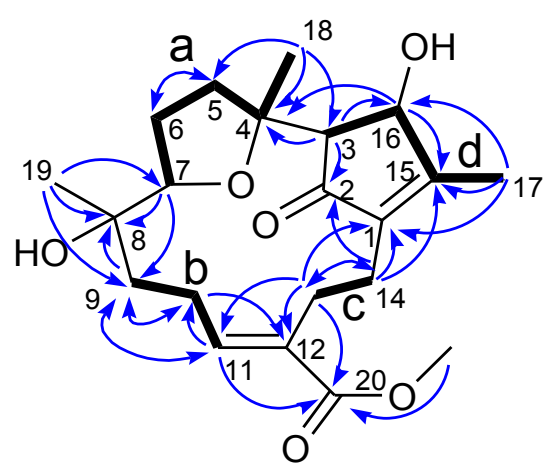

1

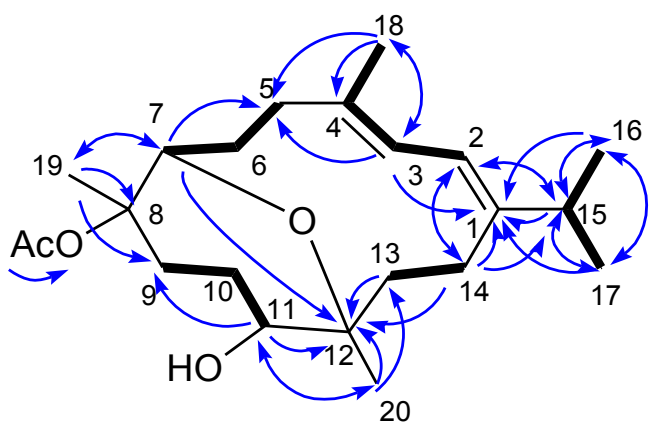

2

\section{- $:^{1} \mathrm{H}-{ }^{1} \mathrm{H}$ COSY correlations \\ $\curvearrowright$ :HMBC correlations}

Figure 4. NOESY correlations of compound 1.

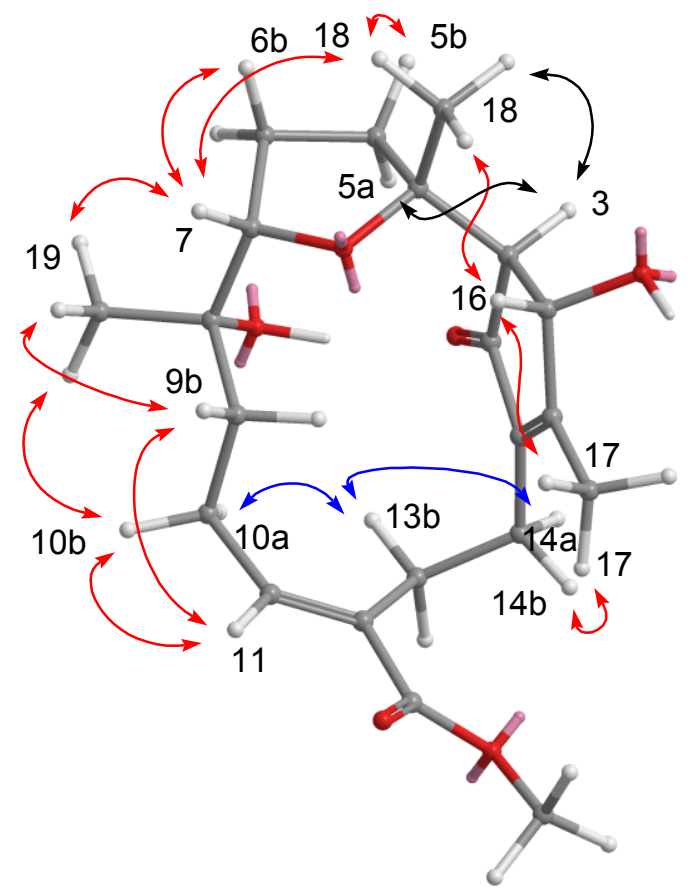

Compound 2 analyzed for $\mathrm{C}_{22} \mathrm{H}_{36} \mathrm{O}_{4}$ from HRESIMS and ${ }^{13} \mathrm{C}$ NMR spectroscopic data (Table 2), corresponding to five degrees of unsaturation. The IR spectrum of 2 at $3445 \mathrm{~cm}^{-1}$ demonstrated a 
broad absorption band diagnostic of hydroxy group. The presence of one oxygenated methine $\left[\delta_{\mathrm{H}} 4.05\right.$ $(\mathrm{t}, 1 \mathrm{H}, J=3.2 \mathrm{~Hz})$ and $\left.\delta_{\mathrm{C}} 75.3(\mathrm{C}-7)\right]$ and an oxygenated quaternary carbon $\left[\delta_{\mathrm{C}} 80.4(\mathrm{C}-12)\right]$ implied that an oxygen bridge is probably present between $\mathrm{C}-7$ and $\mathrm{C}-12$, which was supported by the HMBC correlations from $\mathrm{H}-7$ to $\mathrm{C}-12$. The NMR spectroscopic data (Table 2) indicated that 2 possesses an acetoxy $\left[\delta_{\mathrm{H}} 1.66(3 \mathrm{H}, \mathrm{s}) ; \delta_{\mathrm{C}} 169.8,22.1\right]$ and a conjugated diene $\left[\delta_{\mathrm{H}} 6.05(1 \mathrm{H}, \mathrm{d}, J=8.4 \mathrm{~Hz})\right.$ and 6.37 $(1 \mathrm{H}, \mathrm{d}, J=8.4 \mathrm{~Hz}) ; \delta_{\mathrm{C}} 151.0(\mathrm{C}, \mathrm{C}-1), 117.9(\mathrm{CH}, \mathrm{C}-2), 123.5(\mathrm{CH}, \mathrm{C}-3)$, and $\left.132.6(\mathrm{C}, \mathrm{C}-4)\right]$. The above functionalities suggest that metabolite 2 must consist of a 14-membered ring diterpenoid incorporating an oxepane ring, a hydroxy, an acetoxy and a conjugated diene. Correlations deduced from extensive analyses of the ${ }^{1} \mathrm{H}-{ }^{1} \mathrm{H}$ COSY correlations of 2 in $\mathrm{C}_{6} \mathrm{D}_{6}$ enabled initially the establishment of five partial structures. The structural fragments were subsequently interconnected by the $\mathrm{HMBC}$ correlations (Figure 3). Two oxygen bearing carbons at $\delta_{\mathrm{C}} 87.0(\mathrm{C})$ and $78.3(\mathrm{CH})$ were ascribable to $\mathrm{C}-8$ and $\mathrm{C}-11$ on the basis of the HMBC correlations from Me-19 to C-7, C-8, and C-9 and from Me-20 to C-11, C-12, and C-13. The attachment of isopropyl to C-1 was established on the grounds of HMBC correlations from Me-16/Me-17 to C-15 and C-1. The positions of the conjugated double bonds at C-1/C-2 and C-3/C-4 were confirmed by the HMBC cross-peaks from Me-18 to C-3, $\mathrm{C}-4$, and $\mathrm{C}-5$, as well as a COSY correlation between $\mathrm{H}-2$ and $\mathrm{H}-3$. The planar structure of compound 2 was thus elucidated. The relative configuration and the detailed ${ }^{1} \mathrm{H}$ NMR spectroscopic data assignments of $\mathbf{2}$ were determined mainly by the assistance of the NOESY experiment (Figure 5). The crucial NOE correlations between H-2/H-3, H-2/Me-16, H-2/Me-18, H-2/H-15, H-3/H-7 $\left(\delta_{\mathrm{H}}\right.$ $4.05)$, and $\mathrm{H}-3 / \mathrm{H}-14 \mathrm{a}\left(\delta_{\mathrm{H}} 2.64\right)$ indicated that the geometries of the two olefins at $\mathrm{C}-1 / \mathrm{C}-2$ and $\mathrm{C}-3 / \mathrm{C}-4$ were assigned as both $E$. The coupling constant between $\mathrm{H}-2$ and $\mathrm{H}-3\left(J_{2,3}=8.4 \mathrm{~Hz}\right)$ [23] further suggested the s-trans geometry of the conjugated double bonds. Furthermore, the crucial NOE correlations between H-7/H-9a $\left(\delta_{\mathrm{H}} 2.13\right), \mathrm{H}-11 / \mathrm{H}-9 \mathrm{a}, \mathrm{H}-11 / \mathrm{H}-10 \mathrm{a}\left(\delta_{\mathrm{H}} 1.74\right), \mathrm{H}-11 / \mathrm{H}-13 \mathrm{a}\left(\delta_{\mathrm{H}} 1.97\right)$, Me-19/H-6b ( $\left.\delta_{\mathrm{H}} 1.84\right)$, Me-19/H-10b ( $\left.\delta_{\mathrm{H}} 1.78\right)$, Me-20/H-14b, Me-20/H-10b, and H-3/H-14a $\left(\delta_{\mathrm{H}} 2.64\right)$ demonstrated the $7 R^{*}, 8 S^{*}, 11 S^{*}$, and $12 R^{*}$ configurations as depicted in Figure 5. Accordingly, the structure of 2 was determined as $\left(7 R^{*}, 8 S^{*}, 11 S^{*}, 12 R^{*}, 1 Z, 3 E\right)-8$-acetoxy-11-hydroxy-7, 12-epoxycembra-1(2),3-diene.

Figure 5. NOESY correlations of compound 2.

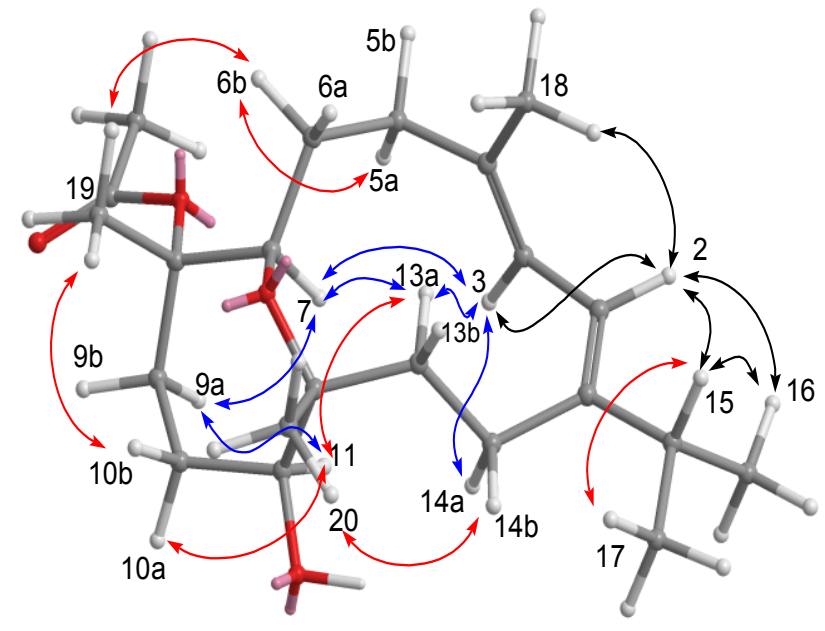


Table 2. NMR data for compound 2.

\begin{tabular}{|c|c|c|c|c|c|}
\hline Position & $\delta_{\mathrm{H}}^{\mathrm{a}}(J$ in $\mathrm{Hz})$ & $\delta_{\mathrm{C}}^{\mathrm{b}}$, type & HMBC & COSY & NOESY \\
\hline 1 & & $151.0, \mathrm{qC}$ & & & \\
\hline 2 & $6.05, \mathrm{~d}(8.4)$ & $117.9, \mathrm{CH}$ & 14,15 & & $3,15,16,18$ \\
\hline 3 & $6.37, \mathrm{~d}(8.4)$ & $123.5, \mathrm{CH}$ & 5,18 & 18 & $2,7,13 a, 14 a$ \\
\hline 4 & & $132.6, \mathrm{qC}$ & & & \\
\hline $5 a$ & $2.10, \mathrm{~m}$ & \multirow{2}{*}{$37.9, \mathrm{CH}_{2}$} & 2 & $6 a$ & $6 b$ \\
\hline $5 b$ & 2.27, m & & & & \\
\hline $6 a$ & $2.04, \mathrm{~m}$ & \multirow{2}{*}{$30.8, \mathrm{CH}_{2}$} & & $5 \mathrm{a}, 7$ & \\
\hline $6 b$ & $1.84, \mathrm{~m}$ & & & 7 & $5 a, 19$ \\
\hline 7 & $4.05, \mathrm{t}(3.2)$ & $75.3, \mathrm{CH}$ & & $6 a, 6 b$ & $3,9 a, 13 a$ \\
\hline 8 & & $87.0, \mathrm{qC}$ & & & \\
\hline $9 a$ & $2.13, \mathrm{~m}$ & \multirow{2}{*}{$36.6, \mathrm{CH}_{2}$} & & & 7,11 \\
\hline $9 b$ & $2.09, \mathrm{~m}$ & & & $10 \mathrm{a}$ & \\
\hline $10 \mathrm{a}$ & $1.74 \mathrm{~m}$ & \multirow{2}{*}{$29.2, \mathrm{CH}_{2}$} & & $9 b$ & \\
\hline $10 \mathrm{~b}$ & $1.08, \mathrm{~m}$ & & & 11 & 19,20 \\
\hline 11 & 3.16 , dd $(10.0,2.8)$ & $78.3, \mathrm{CH}$ & & $10 \mathrm{~b}$ & $9 \mathrm{a}, 10 \mathrm{a}, 13 \mathrm{a}$ \\
\hline 12 & & $80.4, \mathrm{qC}$ & & & \\
\hline $13 \mathrm{a}$ & 1.97, m & \multirow{2}{*}{$37.4, \mathrm{CH}_{2}$} & 12 & $14 \mathrm{a}$ & $3,7,11$ \\
\hline $13 b$ & $1.82, \mathrm{~m}$ & & & $14 b$ & \\
\hline $14 \mathrm{a}$ & $2.64, \mathrm{~m}$ & \multirow{2}{*}{$24.3, \mathrm{CH}_{2}$} & 1 & $13 \mathrm{a}$ & 3 \\
\hline $14 \mathrm{~b}$ & $1.81, \mathrm{~m}$ & & 1 & $13 b$ & \\
\hline 15 & $2.32, \mathrm{~m}$ & $36.9, \mathrm{CH}$ & $1,16,17$ & & $2,16,17$ \\
\hline 16 & $1.06, \mathrm{~d}(6.8)$ & $21.5, \mathrm{CH}_{3}$ & $1,15,17$ & 15 & 2,15 \\
\hline 17 & $1.04, \mathrm{~d}(6.8)$ & $21.8, \mathrm{CH}_{3}$ & $1,15,16$ & 15 & 15 \\
\hline 18 & $1.76, \mathrm{~s}$ & $17.9, \mathrm{CH}_{3}$ & $3,4,5$ & 3 & 2 \\
\hline 19 & $1.48, \mathrm{~s}$ & $18.9, \mathrm{CH}_{3}$ & $7,8,9$ & & $6 b, 10 b$ \\
\hline 20 & $1.11, \mathrm{~s}$ & $18.1, \mathrm{CH}_{3}$ & $11,12,13$ & & $10 b, 14 b$ \\
\hline 21 & & $169.8, \mathrm{qC}$ & & & \\
\hline $\mathrm{OAc}$ & $1.66, \mathrm{~s}$ & $22.1, \mathrm{CH}_{3}$ & 21 & & \\
\hline
\end{tabular}

The cytotoxicities of compounds $\mathbf{1}$ and $\mathbf{2}$ against P-388 (mouse lymphocytic leukemia), HT-29 (human colon adenocarcinoma) tumor cells, and human embryonic lung (HEL) cells are shown in Table 3. Compounds $\mathbf{1}$ and $\mathbf{2}$ were also examined for antiviral activity against human cytomegalovirus (HCMV) using a human embryonic lung (HEL) and displayed antiviral activity against human cytomegalovirus, with $\mathrm{EC}_{50 \mathrm{~s}}$ of 20 and $8.0 \mu \mathrm{g} / \mathrm{mL}$, respectively.

Table 3. Cytotoxicity and anti-HCMV activity of $\mathbf{1}$ and $\mathbf{2}$.

\begin{tabular}{cccccc}
\hline \multirow{2}{*}{ Compounds } & \multicolumn{5}{c}{$\mathbf{E C}_{\mathbf{5 0}}(\boldsymbol{\mu} \mathbf{g} / \mathbf{m L})$} \\
\cline { 2 - 6 } & $\mathbf{A 5 4 9}$ & HT-29 & P-388 & HEL & Anti-HCMV \\
\hline $\mathbf{1}$ & $>50$ & $>50$ & 25.9 & $>50$ & 20 \\
$\mathbf{2}$ & $>50$ & $>50$ & 24.7 & $>50$ & 8.0 \\
\hline
\end{tabular}




\section{Experimental Section}

\subsection{General Experimental Procedures}

Optical rotations were determined with a JASCO P1020 digital polarimeter. UV and IR spectra were obtained on JASCO V-650 and JASCO FT/IR-4100 spectrophotometers, respectively. NMR spectra were recorded on a Varian MR $400 \mathrm{NMR}$ spectrometer at $400 \mathrm{MHz}$ for ${ }^{1} \mathrm{H}$ and $100 \mathrm{MHz}$ for ${ }^{13} \mathrm{C}$. ${ }^{1} \mathrm{H}$ NMR chemical shifts are expressed in $\delta(\mathrm{ppm})$ referring to the solvent peak $\delta_{\mathrm{H}} 7.27$ for $\mathrm{CHCl}_{3}$ or $\delta_{\mathrm{H}} 7.15$ for $\mathrm{C}_{6} \mathrm{D}_{6}$, and coupling constants are expressed in Hertz $(\mathrm{Hz}) .{ }^{13} \mathrm{C}$ NMR chemical shifts are expressed in $\delta(\mathrm{ppm})$ referring to the solvent peak $\delta_{\mathrm{C}} 77.0$ for $\mathrm{CDCl}_{3}$ or $\delta_{\mathrm{C}} 128.0$ for $\mathrm{C}_{6} \mathrm{D}_{6}$. MS were recorded by a Bruker APEX II mass spectrometer. Silica gel 60 (Merck, Germany, 230-400 mesh) and LiChroprep RP-18 (Merck, 40-63 $\mu \mathrm{m}$ ) were used for column chromatography. Precoated silica gel plates (Merck, Kieselgel $60 \mathrm{~F}_{254}, 0.25 \mathrm{~mm}$ ) and precoated RP-18 $\mathrm{F}_{254 \mathrm{~s}}$ plates (Merck) were used for thin-layer chromatography (TLC) analysis. High-performance liquid chromatography (HPLC) was carried out using a Hitachi L-7100 pump equipped with a Hitachi L-7400 UV detector at $220 \mathrm{~nm}$ together with a semi-preparative reversed-phased column (Merck, Hibar LiChrospher RP-18e, $5 \mu \mathrm{m}$, $250 \times 25 \mathrm{~mm})$.

\subsection{Biological Material}

The soft coral S. ehrenbergi was collected by SCUBA at San-Hsian-Tai, Taitong County, Taiwan, in July 2009 at a depth of $6 \mathrm{~m}$ and stored in a freezer until extraction. The voucher specimen (ST-13) was identified by Professor Chang-Feng Dai, National Taiwan University and deposited at the Department of Marine Biotechnology and Resources, National Sun Yat-sen University, Taiwan.

\subsection{Extraction and Isolation}

A specimen of soft coral S. ehrenbergi $(2.0 \mathrm{~kg})$ was minced and extracted with acetone $(4 \times 2 \mathrm{~L})$ at room temperature. The combined acetone extracts were then partitioned between $\mathrm{H}_{2} \mathrm{O}$ and EtOAc. The resulting EtOAc extract (23.8 g) was subjected to gravity silica gel 60 column chromatography (Si $60 \mathrm{CC}$ ) using $n$-hexane and $n$-hexane/EtOAc of increasing polarity, to give 20 fractions. Fraction 14 (2.0 g), eluted with $n$-hexane/EtOAc (10:1), was further subjected to Sephadex LH-20 (acetone) to give 7 subfractions. The fraction 14-2-2 $(0.108 \mathrm{~g})$, was further subjected to RP-18 flash column $\left(\mathrm{MeOH} / \mathrm{H}_{2} \mathrm{O}, 60: 40\right.$ to $\left.100 \% \mathrm{MeOH}\right)$ to give 5 fractions. A subfraction 14-2-2-4 (12.9 mg), was purified by RP-18 HPLC (MeOH/ $\left.\mathrm{H}_{2} \mathrm{O}, 85: 15\right)$ to afford $2(2.3 \mathrm{mg}, 0.0012 \%)$. The fraction $19(0.2 \mathrm{~g})$, eluted with $n$-hexane/EtOAc (1:8), was further subjected to RP-18 flash column $\left(\mathrm{MeOH} / \mathrm{H}_{2} \mathrm{O}, 50: 50\right.$ to $100 \% \mathrm{MeOH})$ to give 6 fractions. The subfraction 19-1, eluted with $\mathrm{MeOH} / \mathrm{H}_{2} \mathrm{O}$ (50:50), was purified by RP-18 HPLC (MeOH/ $\left.\mathrm{H}_{2} \mathrm{O}, 50: 50\right)$ to afford $1(2.1 \mathrm{mg}, 0.001 \%)$.

Ehrenbergol C (1): White amorphous powder; $[\alpha]_{\mathrm{D}}^{25}+95.0\left(c 0.2, \mathrm{CHCl}_{3}\right) ; \mathrm{UV}(\mathrm{MeOH}) \lambda_{\max }(\log \varepsilon)$ $223(3.42) \mathrm{nm}$; IR (neat) $v_{\max } 3444,2975,2929,1696,1652,1439,1385,1284,1192,1087,1038$, $754 \mathrm{~cm}^{-1} ;{ }^{1} \mathrm{H}$ NMR $\left(\mathrm{CDCl}_{3}, 400 \mathrm{MHz}\right)$ and ${ }^{13} \mathrm{C} \mathrm{NMR}\left(\mathrm{CDCl}_{3}, 100 \mathrm{MHz}\right)$ data in Table 1; HRESIMS $m / z 401.1939[\mathrm{M}+\mathrm{Na}]^{+}$(calcd for $\mathrm{C}_{21} \mathrm{H}_{30} \mathrm{O} 6 \mathrm{Na}, 401.1940$ ). 
Acetyl ehrenberoxide B (2): White amorphous powder; $[\alpha]_{\mathrm{D}}^{25}+25.0\left(c 0.2, \mathrm{CHCl}_{3}\right)$; $\mathrm{UV}(\mathrm{MeOH})$ $\lambda_{\max }(\log \varepsilon) 242(3.2) \mathrm{nm}$; IR (neat) $v_{\max }$ 3445, 2957, 2871, 1733, 1456, 1377, 1258, 1088, 1034, $772 \mathrm{~cm}^{-1}$; ${ }^{1} \mathrm{H}$ NMR $\left(\mathrm{C}_{6} \mathrm{D}_{6}, 400 \mathrm{MHz}\right)$ and ${ }^{13} \mathrm{C}$ NMR $\left(\mathrm{C}_{6} \mathrm{D}_{6}, 100 \mathrm{MHz}\right)$ data in Table 1; HRESIMS $m / z 387.2512[\mathrm{M}+\mathrm{Na}]^{+}$(calcd for $\mathrm{C}_{22} \mathrm{H}_{36} \mathrm{O} 4 \mathrm{Na}, 387.2511$ ).

\subsection{Cytotoxicity Assay}

Cytotoxicity was determined on P-388 (mouse lymphocytic leukemia), HT-29 (human colon adenocarcinoma), and A-549 (human lung epithelial carcinoma) tumor cells using a modification of the MTT colorimetric method according to a previously described procedure [24-26]. The provision of the P-388 cell line was supported by J.M. Pezzuto, formerly of the Department of Medicinal Chemistry and Pharmacognosy, University of Illinois at Chicago. HT-29 and A-549 cell lines were purchased from the American Type Culture Collection. To measure the cytotoxic activities of tested compounds, five concentrations with three replications were performed on each cell line. Mithramycin was used as a positive control.

\subsection{Anti-HCMV Assay}

To determine the effects of natural products upon HCMV cytopathic effect (CPE), confluent human embryonic lung (HEL) cells grown in 24-well plates were incubated for $1 \mathrm{~h}$ in the presence or absence of various concentrations of tested natural products with three replications. Ganciclovir was used as a positive control. Then, cells were infected with HCMV at an input of $1000 \mathrm{pfu}$ (plaque forming units) per well of a 24-well dish. Antiviral activity was expressed as $\mathrm{IC}_{50}(50 \%$ inhibitory concentration), or compound concentration required to reduce virus induced CPE by $50 \%$ after 7 days as compared with the untreated control. To monitor the cell growth upon treating with natural products, an MTT-colorimetric assay was employed [26-28].

\section{Conclusions}

This investigation of Taiwanese soft coral $S$. ehrenbergi collected has led to the isolation of two new ehrenbergol $\mathrm{C}$ and acetyl ehrenberoxide B (1 and 2). The carbon framework of $\mathbf{1}$ was identical to a cytotoxic diterpene, lobocrasol isolated from soft coral Lobophytum crassum. However, the stereochemistry of C-7 and C-8 of $\mathbf{1}$ were different from lobocrasol. Compounds $\mathbf{1}$ and $\mathbf{2}$ were not cytotoxic towards P-388 (mouse lymphocytic leukemia), HT-29 (human colon adenocarcinoma) tumor cells, and human embryonic lung (HEL) cells. However, compounds $\mathbf{1}$ and $\mathbf{2}$ displayed antiviral activity towards human cytomegalovirus, with $\mathrm{IC}_{50}$ of 20 and $8.0 \mu \mathrm{g} / \mathrm{mL}$, respectively.

\section{Acknowledgments}

This research was financially supported by grants from the National Science Council (NSC102-2320-B-110-003-MY3) and NSYSUKMU Joint Project (NSYSUKMU 2013-P018) awarded to Chang-Yih Duh. 


\section{References}

1. Blunt, J.W.; Copp, B.R.; Hu, W.-P.; Munro, M.H.G.; Northcote, P.T.; Prinsep, M.R. Marine natural products. Nat. Prod. Rep. 2009, 26, 170-244.

2. Coll, J.C. The chemistry and chemical ecology of octocorals (Coelenterata, Anthozoa, Octocorallia). Chem. Rev. 1992, 92, 613-631.

3. Gross, H.; Wright, A.D.; Beil, W.; König, G.M. Two new bicyclic cembranolides from a new Sarcophyton species and determination of the absolute configuration of sarcoglaucol-16-one. Org. Biomol. Chem. 2004, 2, 1133-1138.

4. Huang, H.-C.; Ahmed, A.F.; Su, J.-H.; Chao, C.-H.; Wu, Y.-C.; Chiang, M.Y.; Sheu, J.-H. Crassocolides A-F, new cembranoids with a trans-fused lactone from the soft coral Sarcophyton crassocaule. J. Nat. Prod. 2006, 69, 1554-1559.

5. Zhang, C.; Li, J.; Su, J.; Liang, Y.; Yang, X.; Zheng, K.; Zeng, L. Cytotoxic diterpenoids from the soft coral Sarcophyton crassocaule. J. Nat. Prod. 2006, 69, 1476-1480.

6. Feller, M.; Rudi, A.; Berer, N.; Goldberg, I.; Stein, Z.; Benayahu, Y.; Schleyer, M.; Kashman, Y. Isoprenoids of the soft coral Sarcophyton glaucum: Nyalolide, a new biscembranoid, and other terpenoids. J. Nat. Prod. 2004, 67, 1303-1308.

7. El Sayed, K.A.; Hamann, M.T.; Waddling, C.A.; Jensen, C.; Lee, S.K.; Dunstan, C.A.; Pezzuto, J.M. Structurally novel bioconversion products of the marine natural product sarcophine effectively inhibit JB6 cell transformation. J. Org. Chem. 1998, 63, 7449-7455.

8. Yan, X.-H.; Gavagnin, M.; Cimino, G.; Guo, Y.-W. Two new biscembranes with unprecedented carbon skeleton and their probable biogenetic precursor from the Hainan soft coral Sarcophyton latum. Tetrahedron Lett. 2007, 48, 5313-5316.

9. Cheng, Y.-B.; Shen, Y.-C.; Kuo, Y.-H.; Khalil, A.T. Cembrane diterpenoids from the Taiwanese soft coral Sarcophyton stolidotum. J. Nat. Prod. 2008, 71, 1141-1145.

10. Iwagawa, T.; Nakamura, S.; Masuda, T.; Okamura, H.; Nakatani, M.; Siro, M. Irregular cembranoids containing a 13-membered carbocyclic skeleton isolated from a soft coral, Sarcophyton species. Tetrahedron 1995, 51, 5291-5298.

11. Sawant, S.; Youssef, D.; Mayer, A.; Sylvester, P.; Wali, V.; Arant, M.; El Sayed, K. Anticancer and anti-inflammatory sulfur-containing semisynthetic derivatives of sarcophine. Chem. Pharm. Bull. 2006, 54, 1119-1123.

12. Badria, F.A.; Guirguis, A.N.; Perovic, S.; Steffen, R.; Müller, W.E.G.; Schröder, H.C. Sarcophytolide: A new neuroprotective compound from the soft coral Sarcophyton glaucum. Toxicology 1998, 131, 133-143.

13. Bishara, A.; Rudi, A.; Benayahu, Y.; Kashman, Y. Three biscembranoids and their monomeric counterpart cembranoid, a biogenetic Diels-Alder precursor, from the soft coral Sarcophyton elegans. J. Nat. Prod. 2007, 70, 1951-1954.

14. Sawant, S.; Youssef, D.; Reiland, J.; Ferniz, M.; Marchtti, D.; El Sayed, K.A. Biocatalytic and antimetastatic studies of the marine cembranoids sarcophine and 2-epi-16-deoxysarcophine. J. Nat. Prod. 2006, 69, 1010-1013. 
15. Cuong, N.X.; Tuan, T.A.; Kiem, P.V.; Minh, C.V.; Choi, E.M.; Kim, Y.H. New cembranoid diterpenes from the Vietnamese soft coral Sarcophyton mililatensis stimulate osteoblastic differentiation in MC3T3-E1 cells. Chem. Pharm. Bull. 2008, 56, 988-992.

16. Wang, S.-K.; Duh, C.-Y. New cytotoxic cembranolides from the soft coral Lobophytum michaelae. Mar. Drugs 2012, 10, 306-318.

17. Lin, S.-T.; Wang, S.-K.; Duh, C.-Y. Cembranoids from the Dongsha atoll soft coral Lobophytum crassum. Mar. Drugs 2011, 9, 2705-2716.

18. Cheng, S.-Y.; Chen, P.-W.; Chen, H.P.; Wang, S.-K.; Duh, C.-Y. New cembranolides from the Dongsha atoll soft coral Lobophytum durum. Mar. Drugs 2011, 9, 1307-1318.

19. Cheng, S.-Y.; Wang, S.-K.; Chiou, S.-F.; Hsu, C.-H.; Dai, C.-F.; Chiang, M.Y.; Duh, C.-Y. Cembranoids from the octocoral Sarcophyton ehrenbergi. J. Nat. Prod. 2010, 73, 197-203.

20. Wang, S.-K.; Hsieh, M.-K.; Duh, C.-Y. Three new Cembranoids from the Taiwanese soft coral Sarcophyton ehrenbergi. Mar. Drugs 2012, 10, 1433-1444.

21. Cheng, S.-Y.; Chiou, S.-F.; Tsai, C.-W.; Wang, S.-K.; Hsu, C.-H.; Dai, C.-F.; Chiang, M.Y.; Wang, W.-H.; Duh, C.-Y. Ceramide and cerebrosides from the octocoral Sarcophyton ehrenbergi. J. Nat. Prod. 2009, 72, 465-468.

22. Lin, S.-T.; Wang, S.-K.; Cheng, S.-Y.; Duh, C.-Y. Lobocrasol, a new diterpenoid from the soft coral Lobophytum crassum. Org. Lett. 2009, 11, 3012-3014.

23. Shin, J.; Fenical, W.; Stout, T.J.; Clardy, J. New cembradiene diterpenoids from an undescribed Caribbean gorgonian of the genus Eunicea. Tetrahedron 1993, 49, 515-524.

24. Geran, R.I.; Greenberg, N.H.; MacDonald, M.M.; Schumacher, A.M.; Abbott, B.J. Protocols for screening chemical agents and natural products against animal tumors and other biological syatems. Cancer Chemother. Rep. 1972, 3, 1-91.

25. Hou, R.-S.; Duh, C.-Y.; Chiang, M.Y.; Lin, C.-N. Sinugibberol, a new cytotoxic cembranoid diterpene from the soft coral Sinularia gibberosa. J. Nat. Prod. 1995, 58, 1126-1130.

26. Chen, W.-H.; Wang, S.-K.; Duh, C.-Y. Polyhydroxylated steroids from the bamboo coral Isis hippuris. Mar. Drugs 2011, 9, 1829-1839.

27. Stevens, M.; Balzarini, J.; Tabarrini, O.; Andrei, G.; Snoeck, R.; Cecchetti, V.; Fravolini, A.; de Clercq, E.; Pannecouque, C. Cell-dependent interference of a series of new 6-aminoquinolone derivatives with viral (HIV/CMV) transactivation. J. Antimicrob. Chemother. 2005, 56, 847-855.

28. Cheng, S.-Y.; Huang, K.-J.; Wang, S.-K.; Duh, C.-Y. Capilloquinol: A novel farnesyl quinol from the Dongsha atoll soft coral Sinularia capillosa. Mar. Drugs 2011, 9, 1469-1476.

(C) 2013 by the authors; licensee MDPI, Basel, Switzerland. This article is an open access article distributed under the terms and conditions of the Creative Commons Attribution license (http://creativecommons.org/licenses/by/3.0/). 